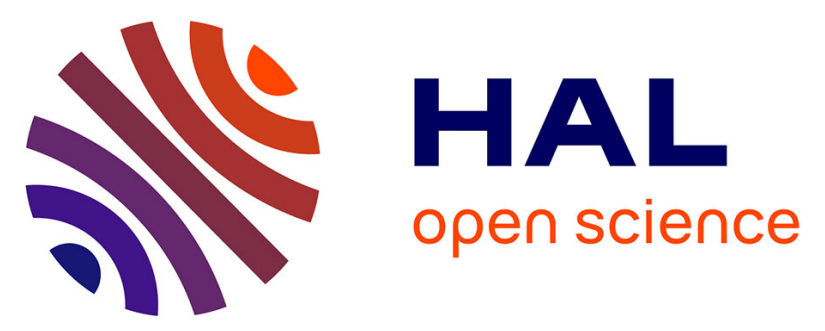

\title{
Evolution of Taman Peninsula's ancient Bosphorus channels, south-west Russia: Deltaic progradation and Greek colonisation
}

\author{
Matthieu Giaime, Simona Avnaim-Katav, Christophe Morhange, Nick \\ Marriner, Frauke Rostek, Alexey V Porotov, Alexandre Baralis, David \\ Kaniewski, Helmut Brückner, Daniel Kelterbaum
}

\section{To cite this version:}

Matthieu Giaime, Simona Avnaim-Katav, Christophe Morhange, Nick Marriner, Frauke Rostek, et al.. Evolution of Taman Peninsula's ancient Bosphorus channels, south-west Russia: Deltaic progradation and Greek colonisation. Journal of Archaeological Science: Reports, 2016, 25, pp.327-335. 10.1016/j.jasrep.2015.11.026 . hal-01760257

\section{HAL Id: hal-01760257 \\ https://hal.science/hal-01760257}

Submitted on 28 Apr 2020

HAL is a multi-disciplinary open access archive for the deposit and dissemination of scientific research documents, whether they are published or not. The documents may come from teaching and research institutions in France or abroad, or from public or private research centers.
L'archive ouverte pluridisciplinaire $\mathbf{H A L}$, est destinée au dépôt et à la diffusion de documents scientifiques de niveau recherche, publiés ou non, émanant des établissements d'enseignement et de recherche français ou étrangers, des laboratoires publics ou privés. 


\title{
Evolution of Taman Peninsula's ancient Bosphorus channels, south-west Russia: Deltaic progradation and Greek colonisation
}

\author{
Matthieu Giaime ${ }^{\mathrm{a}, *}$, Simona Avnaim-Katav ${ }^{\mathrm{b}}$, Christophe Morhange ${ }^{\mathrm{a}, \mathrm{c}}$, Nick Marriner ${ }^{\mathrm{d}}$, Frauke Rostek ${ }^{\mathrm{a}}$, \\ Alexey V. Porotov ${ }^{\mathrm{e}}$, Alexandre Baralis ${ }^{\mathrm{f}}$, David Kaniewski ${ }^{\mathrm{c}, \mathrm{g}}$, Helmut Brückner ${ }^{\mathrm{h}}$, Daniel Kelterbaum ${ }^{\mathrm{h}}$ \\ a Aix Marseille Université, CNRS, CEREGE UMR 7330, Europôle Méditerranéen de l'Arbois, BP 80, 13545 Aix-en-Provence, France \\ b Department of Maritime Civilizations and the Leon Recanati Institute for Maritime Studies (RIMS), University of Haifa, Mount Carmel, Haifa 31905, Israel \\ c Institut Universitaire de France, 103 Boulevard Saint Michel, 75005 Paris, France \\ d CNRS, Laboratoire Chrono-Environnement UMR6249, Université de Franche-Comté, UFR ST, 16 Route de Gray, 25030 Besançon, France \\ e Moscow State University, Faculty of Geography Lomonosov, 119991 Moscow, Lininskie Gori, GSP-1, Russia \\ ${ }^{\mathrm{f}}$ Département des Antiquités Grecques, Etrusques et Romaines du Louvre, Musée du Louvre, 75058 Paris Cedex 01, France \\ ' Université Paul Sabatier-Toulouse 3, CNRS, EcoLab (Laboratoire d'Ecologie Fonctionnelle et Environnement), Bâtiment 4R1, 118 Route de Narbonne, 31062 Toulouse Cedex 9, France \\ ${ }^{\mathrm{h}}$ Institute of Geography, University of Cologne, Köln, Germany
}

\section{A R T I C L E I N F O}

\section{Article history:}

Received 6 July 2015

Received in revised form 16 November 2015

Accepted 18 November 2015

Available online $\mathrm{xxxx}$

\section{Keywords:}

Geoarchaeology

Cimmerian Bosphorus

Taman Peninsula

Kuban River

Phanagoria

Russia

Black sea

\begin{abstract}
A B S T R A C T
This paper presents new data looking into the Holocene evolution of the Kuban delta (Taman Peninsula, SW Russia), with particular emphasis on its southern arm. In the area of the later Taman Peninsula, the Holocene marine transgression created an archipelago around 6000 years ago. When sea-level rise decelerated, deltaic sedimentation and longshore drift gradually landlocked the islands, transforming the archipelago into a peninsula. The peninsula constituted an important area of Greek colonisation in the northern Black Sea because it was conducive to sea-faring, natural anchorages and human settlement. Natural factors such as delta progradation and the evolution of spits and sand bars have considerably affected the landscape evolution and therefore human occupation. After 6000 years ago the progradation of the delta began from the east of the peninsula, where the Kuban River drains into the sea. Navigation by an eastern channel, the Kuban Bosphorus became impossible at least 1500 years before the Greek colonisation. By then, the central Bosphorus (Temryuk Bosphorus) was well suited for sea-faring. The calm shallow-marine and lagoonal areas were a suitable environment for harbours and maritime activities. Nonetheless, the growth of sand spits and barriers at the head of the islands eventually led to the closure of these spaces after the early second millennium BC. Some ancient city-states, such as Golubitskaya 2 or Strelka were abandoned just a few centuries after their foundation.
\end{abstract}

\section{Introduction}

The Taman Peninsula (south-west Russia), separated from the Crimean Peninsula by the Strait of Kerch, lies at the intersection between the Azov Sea to the north and the Black Sea to the south. Recent studies (Porotov, 2007; Brückner et al., 2010; Kelterbaum et al., 2011) have established the existence of a large palaeo-archipelago during antiquity, articulated around four islands. These geomorphological studies confirm the description of the region made by ancient authors. In effect, several ancient Greek historians and geographers have described at least one island in place of the present peninsula. For instance, Hecataeus of Miletus, during the 5th century BC, described ancient Phanagoria (or Phanagoreia) on one of these islands (Hecat. Milet. 164 FHG [212 FGH]). Five centuries later, Strabo, referred to the same island, where the city of Kepoi stood, explaining that it was separated from the

\footnotetext{
* Corresponding author.

E-mail address: matthieu.giaime@gmail.com (M. Giaime).
}

land by an arm of the ancient Kuban (Anticites or Hypanis) (Strabo, 11.2.9/11.2.10), a description that is supported by Pomponius Mela (description of the known world, I. 19.21.). It is upon the shores of these islands that the first Greek colonists, originally from Ionia, and mainly coming from Miletus, founded their settlements in the second quarter of the 6th century BC, in search of the rich fish resources offered by the Maeotis Lake (Azov Sea) (Kuznetsov, 2003; Finogenova, 2003; Abramov and Zavoykin, 2003). Among other settlements, they founded Hermonassa, Kepoi and Petraeus. Subsequently, the advance of Persian forces in Asia Minor, under the leadership of General Harpagus, forced the inhabitants of Teos to seek refuge on the banks of the Cimmerian Bosphorus where they settled around 545 BC at Phanagoria.

The main objective of our study is to characterise the peninsula's deltaic palaeo-environments and evolution since the Holocene marine transgression around 6000 years ago, and to elucidate the possible presence of a palaeo-Bosphorus on the eastern part of the peninsula. We will compare and contrast our data with a number of recent studies undertaken on the delta in order to obtain a chronology for the closure of the 
Bosphorus channels (Brückner et al., 2010; Kelterbaum et al., 2011; Fouache et al., 2012).

\section{Geological and geomorphological settings}

Taman Peninsula is formed by Miocene and Pliocene rocks composed mainly of marl, sandstone and some limestone outcrops (Fouache et al., 2012). Many of these rocks are exposed at the surface forming small hills surrounded by the Holocene deltaic plain of the Kuban (Fig. 1). These rocky outcrops form an undulating terrain along a series of anticlines and synclines induced by tectonic compression, following the Alpine orogeny (Saintot and Angelier, 2000). The postglacial sea-level rise in the Black Sea is similar to that of the Mediterranean: a rapid glacio-eustatic rise until $6000 \mathrm{BP}$, followed by an important deceleration in sea-level rise (Porotov, 2007; Brückner et al., 2010; Fouache et al., 2012). This relative sea-level rise transformed the area into an extended archipelago of four islands, presently landlocked and connected, due to the progradation of the Kuban delta and the evolution of sand barriers by longshore drift. The coastlines of the former islands were, like nowadays, composed of $>20$-m-high cliffs.

The Kuban draws its source in the northern Caucasus and reaches the Black and Azov seas $850 \mathrm{~km}$ downstream. It is the largest river in this region, both in terms of its size and flow rate $\left(400 \mathrm{~m}^{3} / \mathrm{s}\right)$ (Mikhailov et al., 2002).
Due to the slow-down in global sea-level rise, particularly marked during the last ca. 3000 years, most Mediterranean and Black Sea deltas have undergone significant progradation (e.g., Brückner et al., 2005; Anthony et al., 2014). This geomorphological evolution has also affected the coasts of the Taman Peninsula, leading to a straightening of the coastline and an infilling of its rias by fluvially-derived deposits. Significant sediment inputs have accelerated the infilling of the peninsula's lagoons and, even more important and at a larger scale, of its ancient harbours leading to a displacement of coastal populations (Morhange and Marriner, 2010). Such natural constraints have undoubtedly impacted upon the human geography of the peninsula as a result of deltaic progradation.

\section{Historical and archaeological contexts}

Taking advantage of the departure of the Cimmerian populations, which resulted from the Scythian expansion in the Azov region (Strabo, XI, 2, 5), Greek colonists from Ionia settled on the Taman seaboard during the first half of the 6th century BC. The Azov Sea was renowned for its fishing industry, notably specialised in the export of salted fish (Strabo, 11, 2, 4). The colonists allowed the inhabitants of the Bosphorus, through the successive trading posts built upon the shores of the Don delta, to spread the goods of nomadic populations from the steppes to the Black and Aegean Seas. Ancient Greek cities were active trade

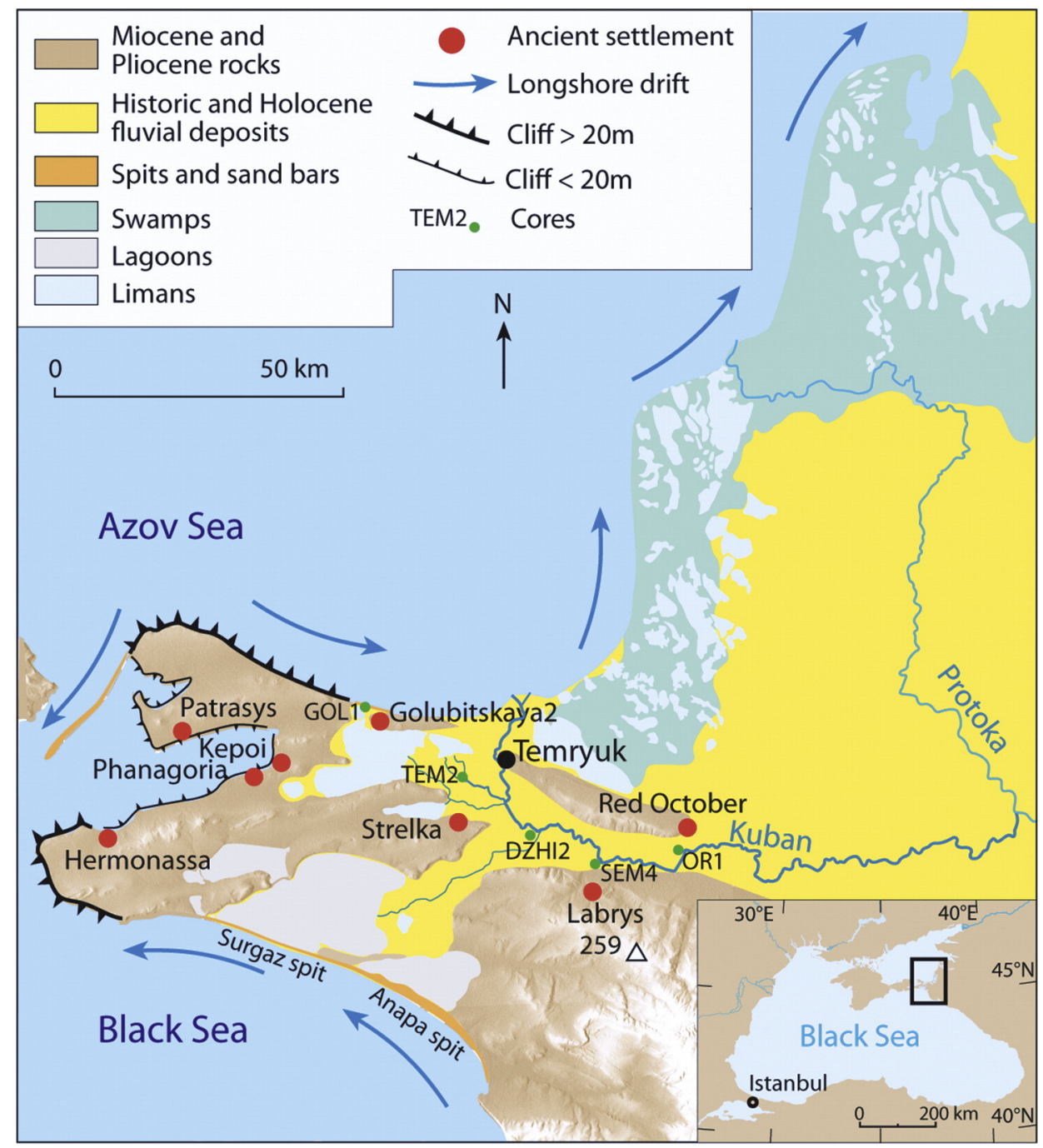

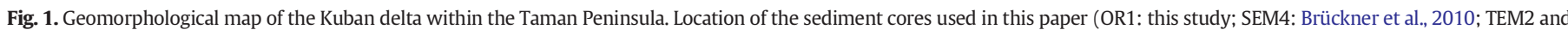
GOL1: Kelterbaum et al., 2011; DZHI2: Fouache et al., 2012). 
interfaces with their own agricultural land. Respective limitations on each city area are still difficult to understand; however, archaeological research conducted on the peninsula since 1852 has revealed ca. 175 settlements whose development began in the last quarter of the 6th century BC, with a subsequent boom in the 4th century BC (Müller et al., 1999). This organisation persisted during the Hellenistic and Roman periods, despite the Mithridatic Wars, and then the installation of Sarmatian tribes, which caused a slight decrease in the number of rural settlements between the 2 nd century BC and the 1st century AD (Maslennikov, 2003). Some contemporary field evidence, resulting from the growth of aerial photography and photo-interpretation in the 1950s, corroborated the influence of Greek cities on this space. No less than four of them were superimposed on the peninsula of Fontalovskij, where Kepoi and Patraeus were situated (Garbuzov, 2003).

Despite a short recovery during the 2nd century AD, all of the peninsula's Greek cities fell during the Hun invasions of the 4th century $\mathrm{AD}$, while the proto-Bulgarian intrusions marked the end of the last relics of this agricultural planning (Maslennikov, 2003). This area was particularly conducive to navigation and maritime activities during the late Holocene (Fig. 2).

\section{Methods}

A continuous core was drilled on the Kuban delta in September 2012 $\left(45^{\circ} 9^{\prime} 598^{\prime \prime} \mathrm{N}, 37^{\circ} 39^{\prime} 22.86^{\prime \prime} \mathrm{E} ; 1.50 \mathrm{~m}\right.$ a.s.l.) (Fig. 1). For the palaeoenvironmental reconstruction, bio-sedimentological analyses were performed. Sedimentological analyses help to describe the nature, texture and structure of the sediment. Foraminifera and ostracods were picked under a binocular microscope and identified to species level when possible (Loeblich and Tappan, 1988; Athersuch, 1989; Cimerman and Langer, 1991; Murray, 2006). The core is characterised by several facies of either continental or marine origin. We also determined the provenance of the organic matter in the sediment based on total organic carbon $\left(\mathrm{C}_{\mathrm{org}}\right)$ and nitrogen $(\mathrm{N}) . \mathrm{A} \mathrm{C}_{\mathrm{org}} / \mathrm{N}$ ratio greater than 15 is attributed to terrigenous organic matter; organic matter of aquatic origin is associated with figures lower than or equal to 9 (e.g. Meyers, 1997; Sampei and Matsumoto, 2001). In the coastal zone, a mixing of terrigenous and marine organic matter is common because of fluvial sediment input and coastal erosion (Lamb et al., 2006). Five accelerator mass spectrometry (AMS) radiocarbon $\left({ }^{14} \mathrm{C}\right)$ dates on shortlived samples (seeds and small leaves) and charcoal remains were performed (Table 1$)$. The radiocarbon ages are expressed in calibrated

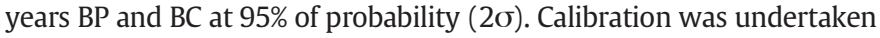
using Calib 7.1. (Stuiver and Reimer, 1993) with the IntCal13 curve (Reimer et al., 2013).

\section{Results for sediment core OR1 (Fig. 3)}

\subsection{Unit A: pre-transgressive facies before $6300 \mathrm{cal}$. BP}

The base of the core is characterised by $120 \mathrm{~cm}$ of relatively fine grey sediment. Sand represents $17 \%$ of the total sediment and contains white mica. The sand fraction tends to decrease towards the top of the unit, where it falls to $3.65 \%$. Planktonic foraminifera species such as Chiloguembelina sp., Subbotina sp., or Hedbergella sp. were only found in the first $80 \mathrm{~cm}$ where the sand fraction is the most important. According to Loeblich and Tappan (1988), these species are fossils from the Palaeogene or Oligocene. Other species like Haynesina germanica and Elphidium crispum are also present. Most of them are damaged; the tests show dissolution marks such as secondary calcite, typical of terrestrial environments (Murray, 2006). In this unit, the $\mathrm{C}_{\text {org }} / \mathrm{N}$ ratio is 19.73 , consistent with terrestrial organic matter. The mixing between allochthonous microfauna from the Palaeogene and the Oligocene and terrigenous organic matter indicates a pre-transgressive terrestrial environment.

\subsection{Unit B: peat layer between 6300 and $6050 \mathrm{cal}$. BP}

The development of a paralic peat is attested between $6340 \pm$ $30 \mathrm{BP}(5370-5295 \mathrm{cal}$. BC) and $6050 \pm 30 \mathrm{BP}(5025-4880 \mathrm{cal}$. BC). Initially, the organic material is mixed with clay. The peat layer sensu stricto is between 830 and $760 \mathrm{~cm}$ depth. For this peat, $\mathrm{C}_{\mathrm{org}} / \mathrm{N}$ ratios are between 13.5 and 16 . The ratio is highest at the top of the unit, reflecting the closure of the environment because of vegetation development.

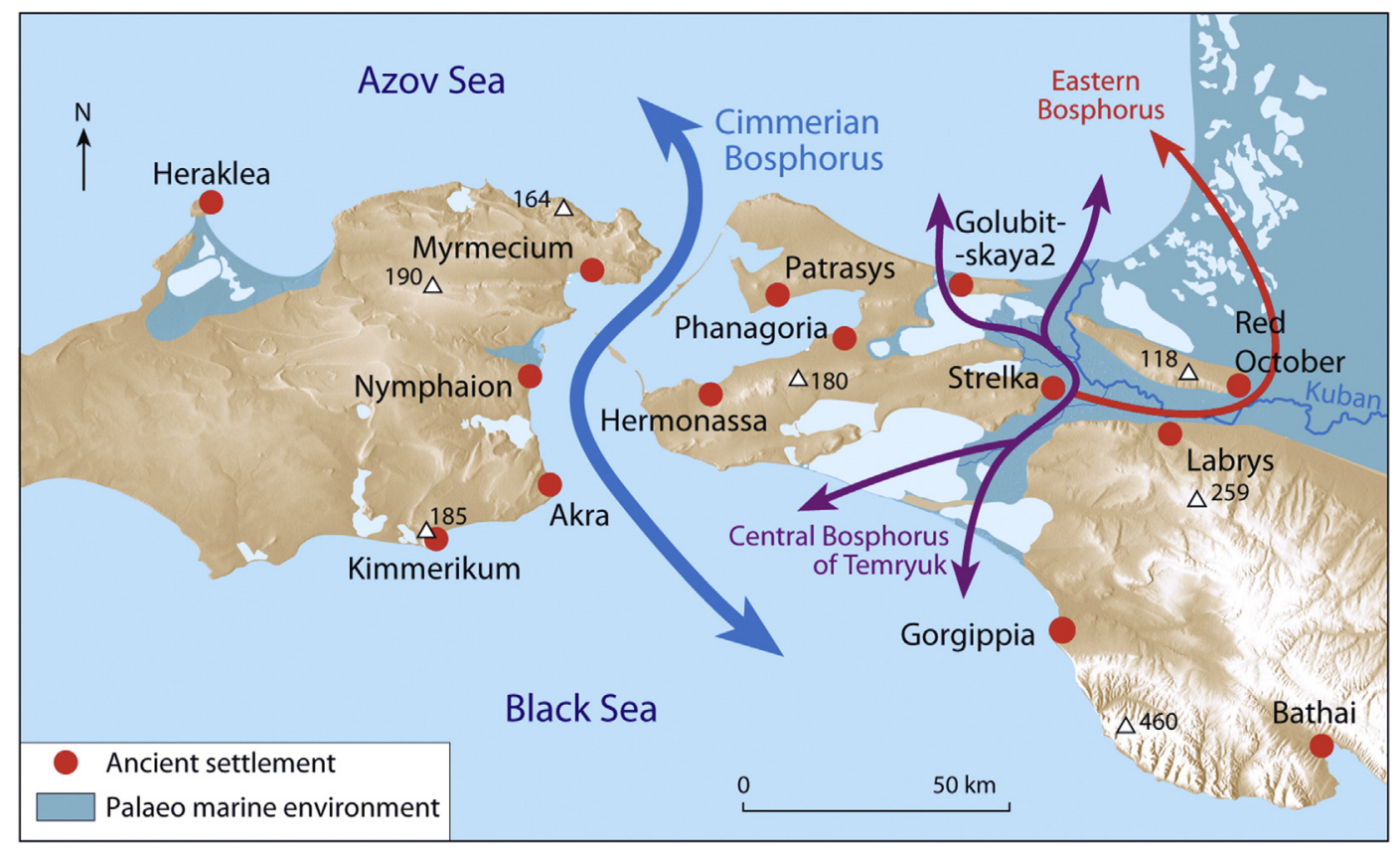

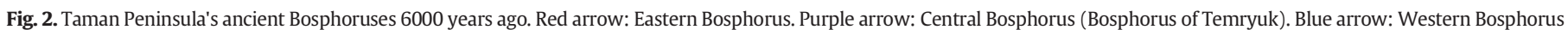
(Cimmerian Bosphorus). (For interpretation of the references to colour in this figure legend, the reader is referred to the web version of this article.) 
Table 1

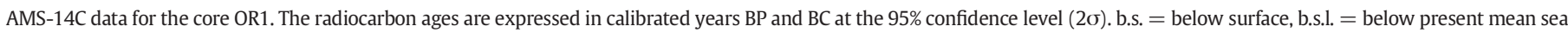
level. Calibration using Calib 7.1. (Stuiver and Reimer, 1993) and the IntCal13 curve ((Reimer et al., 2013)).

\begin{tabular}{|c|c|c|c|c|c|c|c|}
\hline Sample & Lab number & $\delta C^{13}$ & Depth (cm b.s.) & Depth (cm b.s.l.) & Age ${ }^{14} \mathrm{C}$ & 2 sigma BP min; max & 2 sigma $B C \min ; \max$ \\
\hline ORI 44 & Beta-375061 & -26.3 & 568 & 418 & $4130 \pm 30$ & $4825 ; 4530$ & $2875 ; 2580$ \\
\hline ORI 48 & Beta-375062 & -25 & 590 & 440 & $4720 \pm 30$ & $5485 ; 5445$ & $3535 ; 3495$ \\
\hline ORI 81 & Beta-375064 & -23.8 & 790 & 640 & $6050 \pm 30$ & $6975 ; 6830$ & $5025 ; 4880$ \\
\hline ORI 84 & Beta-375063 & -24.5 & 830 & 680 & $6160 \pm 30$ & $7165 ; 6955$ & $5215 ; 5005$ \\
\hline ORI 87 & Beta-375065 & -28.4 & 860 & 710 & $6340 \pm 30$ & $7320 ; 7245$ & $5370 ; 5295$ \\
\hline
\end{tabular}

\subsection{Unit C: marine transgression between 6050 and $4700 \mathrm{cal}$. BP}

Unit C, between 760 and $621 \mathrm{~cm}$, is characterised by a very fine grain size. Silts and clays represent $95 \%$ of the total sediment. Two small peaks of gravel ( $8 \%$ and $14.5 \%$ ) were found at $715 \mathrm{~cm}$ and $695 \mathrm{~cm}$, respectively. The gravel fraction comprises small cemented rocks with some angular and well-rounded continental lithoclasts. The ratio of total organic carbon $\left(\mathrm{C}_{\mathrm{org}}\right)$ and nitrogen $(\mathrm{N})$ is close to 10 , typical of a coastal environment. The association of fragments of bryozoa and numerous dinoflagellate cysts in the middle of the unit (Kaniewski et al., 2015), in addition to its uniform appearance and presence of aquatic organic matter, reflect a protected marine environment. Due to the geography of the site, it is likely that the shallow marine environment, protected from swell and waves, was subjected to terrigenous input from the Kuban (Brückner et al., 2010). All of these factors could cause a mixing of marine and terrigenous organic matter, as in present-day estuaries, where the ratios are similar (Wilson et al., 2005; Lamb et al., 2006).

\subsection{Unit D: peat layer between 4700 and $4100 \mathrm{cal}$. BP}

This peat layer developed between 621 and $540 \mathrm{~cm}$. Both dates obtained show that it was already in place around $4720 \pm 30 \mathrm{BP}$ (3535-3495 cal. BC) and its growth ended around $4130 \pm 30 \mathrm{BP}$ (2875-2580 cal. BC). The final $5 \mathrm{~cm}$ of the unit, and the $5 \mathrm{~cm}$ above, are characterised by the presence of a large number of the lagoonal benthic Ostracoda Cyprideis torosa. This is consistent with the transformation of the environment into a lagoon, bringing peat growth to an end. Indeed, the fact that the $\mathrm{C}_{\mathrm{org}} / \mathrm{N}$ ratio is equal to 16 throughout the peat facies illustrates that the unit was formed in a closed environment, close to the coast but without direct interaction with the sea.

\subsection{Unit E: delta-front deposits in a lagoonal context after $4100 \mathrm{cal} . \mathrm{BP}$}

The environment is characterised by an input of coarser sediments. Indeed, the layer between 620 and $455 \mathrm{~cm}$ is characterised by a sand fraction comprising more than $50 \%$ of the total sediment texture. In addition to the significant presence of $C$. toros $a$ at the base of the unit, and a few individuals of the gastropod Hydrobia ventrosa, fauna in the upper part of the facies is characterised by lagoonal benthic foraminifera such as H. germanica, Aubignyna sp., Porosononion sp. and Ammonia spp. Then, the sand fraction decreases between 455 and $360 \mathrm{~cm}$, which could be due to numerous processes. For instance these could include (1) a decrease in river flow; (2) lateral changes in the position of the main channel; (3) impacts of short climatic fluctuations; and/or (4) channel auto cyclic avulsion/migration processes. The upper part of this unit (between 455 and $390 \mathrm{~cm}$ ) comprises a gradual transition from a lagoonal environment to the deltaic plain. Ammonia spp. disappears and the proportion of $H$. germanica, preferring fine-grained habitats, increases with a concomitant decrease in salinity (Murray, 2006). This phenomenon could be explained by the silting of the lagoon and the delta-front progradation (Reineck and Singh, 1975).

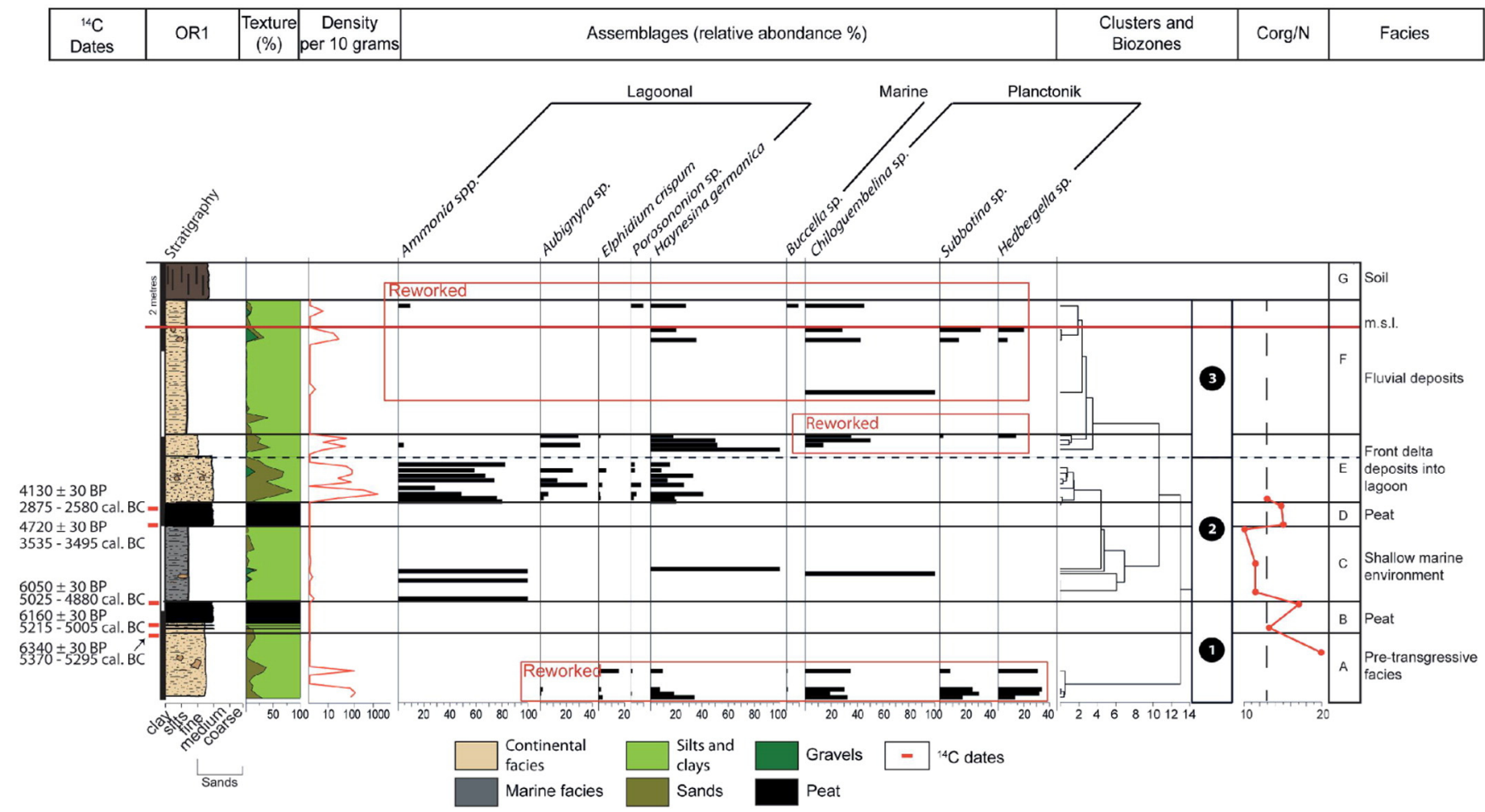

Fig. 3. Synopsis of sediment core OR1 with stratigraphy, density, faunal record (foraminifera) and facies interpretation. 


\subsection{Unit F: fluvial deposits}

Between 390 and $110 \mathrm{~cm}$, the fine fraction is dominant. However, we observe the presence of coarser sediments (gravels) that may correspond to Kuban flooding. The foraminifera found at the top of the core are damaged and several of them are marked by a secondary calcification. They are not in situ, as in the first unit.

\subsection{Unit G: soil}

The upper part of the core OR1, mainly made-up of silts, constitutes the top of the deltaic plain composed of an agricultural soil.

\section{Discussion}

\subsection{Comparison with other studies}

In this part, we compare and contrast our data with several previous surveys (see Fig. 1 for the locations of the cores). The deltaic deposits of the Taman Peninsula constitute a classic transgressive-regressive sequence (Reineck and Singh, 1975).

- Core SEM4 (Brückner et al., 2010) is located on the Kuban flood plain, $12 \mathrm{~km}$ downstream from OR1 $\left(45^{\circ} 08^{\prime} 36.7^{\prime \prime} \mathrm{N}, 37^{\circ} 39^{\prime} 22.86^{\prime \prime} \mathrm{E}\right.$; total depth: $9 \mathrm{~m}$ ). The site is now landlocked more than $20 \mathrm{~km}$ upstream from the river mouth and $30 \mathrm{~km}$ from the Black Sea. The survey was conducted $300 \mathrm{~m}$ north of the settlement of Semebratnee (Labrys).

- Core DZHI2 (Fouache et al., 2012) is located $19 \mathrm{~km}$ from OR1 ( $45^{\circ} 11^{\prime}$ $20.8^{\prime \prime} \mathrm{N}, 37^{\circ} 24^{\prime} 55.5^{\prime \prime} \mathrm{E}$; total depth: $14 \mathrm{~m}$ ) on the lower plain of the
Kuban near the bifurcation into the river's northern (near the Azov Sea) and southern (towards the lagoons bordering the Black Sea) arms.

- Cores TEM2 $\left(45^{\circ} 16^{\prime} 01.88^{\prime \prime} \mathrm{N}, 37^{\circ} 16^{\prime} 38.25^{\prime \prime} \mathrm{E}\right.$; total depth $\left.12 \mathrm{~m}\right)$ and GOL1 $\left(45^{\circ} 20^{\prime} 30.29^{\prime \prime} \mathrm{N}, 37^{\circ} 09^{\prime} 59.82^{\prime \prime} \mathrm{E}\right.$; total depth $10 \mathrm{~m}$ ) (Kelterbaum et al., 2011) are located downstream of the separation of the river near the Azov Sea. GOL1 was carried out in the middle of the sand spit which links the former islands of Golubitskaya and Taman. TEM2 is located in the former Akthanizovskaya Liman, presently being infilled by sediments from the Kuban.

By comparing and contrasting these cores, we have built up a palaeo-geographical story for the progradation of the Kuban delta front. The chronostratigraphy (Fig. 4) underscores the main stages of landscape change on the Taman Peninsula during the past 6000 years (Fig. 5).

Most of the cores reached the pre-transgressive facies, composed of silt or sand. These pre-transgressive environments predate 5500 years cal. BC. The facies have been interpreted as terrestrial environments consistent with a depositional zone for locally eroded sediments.

Between ca. 5450 years cal. BP. and ca. 4950 years cal. BP, a basal transgressive peat layer cuts across the three cores situated upstream. If we take into account the possible error of the radiocarbon ages and the 2 sigma confidence interval, the three layers are of the same age. Moreover, a stratigraphic shift occurs between the upstream cores (OR1 and SEM4) and core DZHI2. Fouache et al. (2012) have attributed this ca. $2 \mathrm{~m}$ stratigraphic offset to sediment compaction on the delta.

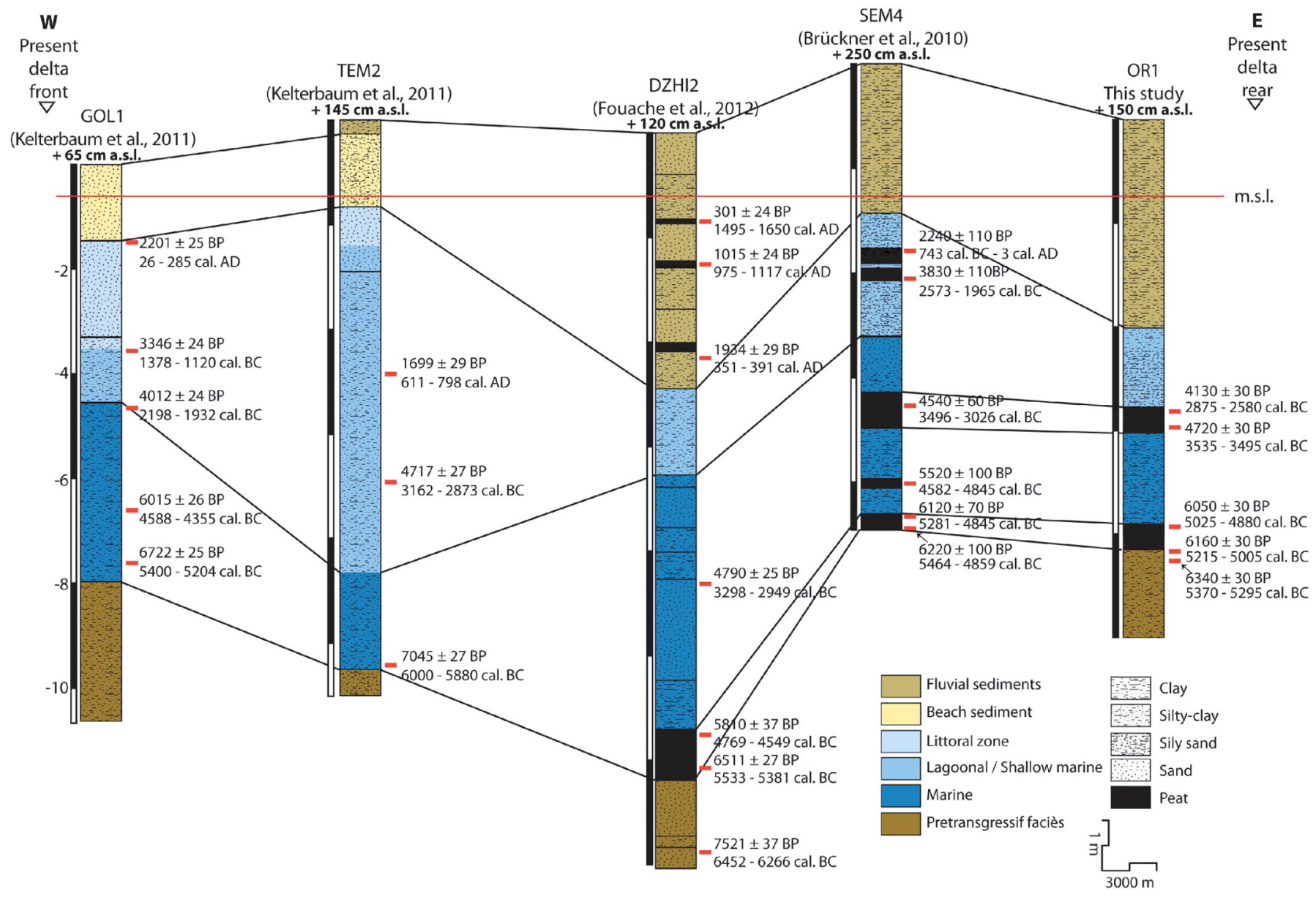

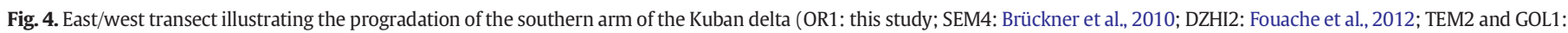
Kelterbaum et al., 2011). 

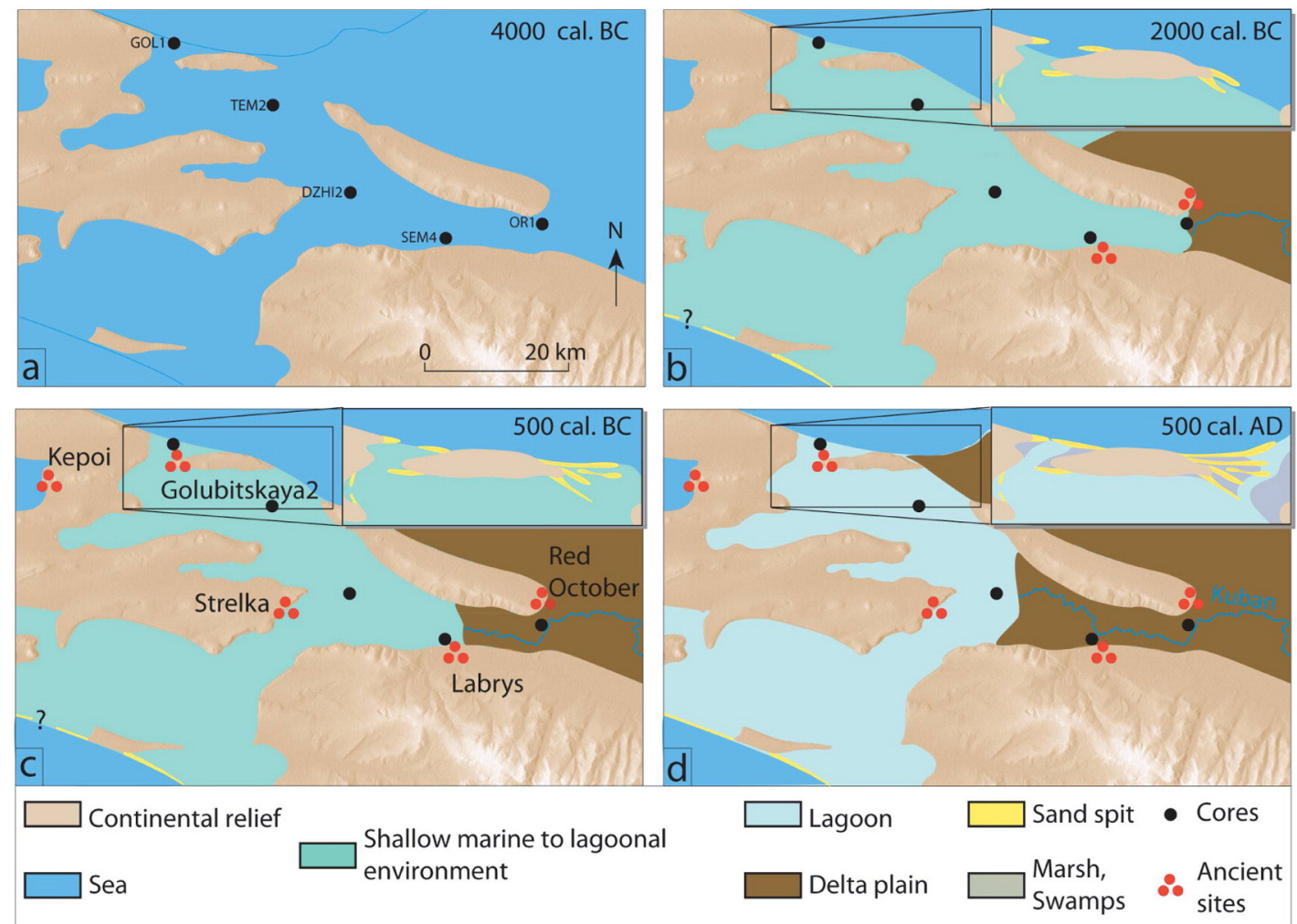

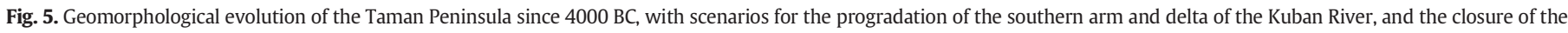
Eastern Bosphorus (Kuban Bosphorus) and later also the Bosphorus of Temryuk. Based on Kelterbaum et al. (2011) and this paper.

This phenomenon is well attested on Mediterranean deltas (Stanley, 1997). Recent studies have reinforced our knowledge about this phenomenon in the Nile (Marriner et al., 2012), the Tiber (Marra et al., 2013), the Po (Teatini et al., 2011) and the Marano-Grado lagoon (Bondesan et al., 1995). However, the layer in question is a basal peat that has undergone less compaction due to its position atop the sandy substratum. Previous studies suggest spatially variable subsidence rates across the peninsula: For example, in the southern part of the Kuban delta, Mikhailov et al. (2002) estimate the rate of subsidence to be $2-6 \mathrm{~mm} /$ year. For Fouache et al. (2005), present-day subsidence is estimated at 3.5-4 mm/year around Temryuk, $10 \mathrm{~km}$ north of the coring site, but they ascribe 2 or $3 \mathrm{~mm}$ to neotectonics. For the Black Sea side, south of the peninsula, they calculate that subsidence since the Upper Pleistocene has been about $2.5 \mathrm{~mm} /$ year. Kaplin and Selivanov (2004) also estimate the rate of subsidence to be around 4.5 or $3 \mathrm{~mm}$ in the central part of the Taman Peninsula. In contrast, upstream, the peninsula is believed to be tectonically stable. Thus, this stratigraphic shift seems to be the result of neotectonics and sediment compaction. A further possibility is that part of this shift could simply be due to the natural slope of the substratum between the cores DZHI2 and SEM4 (0.0002\%).

\subsection{Holocene palaeogeographies landscape evolution}

The maximum Holocene marine ingression into the area of the later Taman Peninsula occurred between ca. 5000 and ca. 3500 years cal. BC (Brückner et al., 2010). This transgression led to the formation of an archipelago of four islands (Fig. 5a), exploited by societies since the Neolithic (Kaniewski et al., 2015).

After a new phase of peat growth, attested in cores OR1 and SEM4 between ca. $3500 \mathrm{cal}$. BC and ca. 2750 years cal. BC, a marine-lagoonal environment formed on the eastern part of the peninsula. Deltaic progradation led to an infilling and straightening of the coastline. This progradation is already marked at the eastern extremity of the Taman Peninsula (core OR1), characterised by a gradual transition from lagoon to flood plain facies at a depth of $4 \mathrm{~m}$. This caused the closure of the waterway between the Black Sea and the Azov Sea to the east of the peninsula (Eastern Bosphorus) at least 1500 years before the Greek colonisation (Fig. 5b).

The upper parts of the cores clearly show an upstream/downstream contrast. In fact, after the deceleration of the marine transgression, the dominant processes were sediment supply and the regularisation of the coast by the growth of sand spits and barriers (Fig. 5c). According to the classification of Coleman and Wright (1975), the whole Kuban delta, like many other deltas in the Mediterranean and the Black Sea, was dominated by both fluvial and wave processes during the midHolocene. Today, the margins of the southern part of the delta (Taman Peninsula) are mostly wave-dominated because of the low sediment inputs. Most of the delta's branches today flow and prograde beyond the limits of the former lagoons (Giaime et al., 2014). Sediment input to the Azov Sea via the smaller northern arm is transported northwards by the longshore drift along the coastline; the delta is not able to prograde beyond the geographic limits of the peninsula.

6.3. Geomorphological impacts on the evolution of the three Bosphorus channels: eastern (Kuban), central (Temryuk) and western (Cimmerian)

The Holocene marine transgression, which shaped the formation of the Taman archipelago, was characterised by three palaeoBosphoruses between four islands. By comparing and contrasting the different studies undertaken on the Kuban delta with our new data, it has been possible to suggest palaeogeographical scenarios for the infilling of the channels. Since ca. $6000 \mathrm{BP}$, these geomorphological changes have led to modifications in the navigation pathways and harbour occupation patterns. Human societies were forced to abandon some anchorages as a result of rapid sedimentation mainly on the eastern edge of the palaeo-archipelago, leading to landlocking and infilling of ancient harbour basins. 


\subsubsection{Eastern Bosphorus (Kuban Bosphorus)}

This strait, connecting the Black and Azov seas on the eastern side of the peninsula, created by the Holocene marine transgression, was washed by the sea between 5000 and $3500 \mathrm{cal}$. BC. This is confirmed by the study of core OR1 and former studies (Brückner et al., 2010). After a phase of peat growth between 3500 and 2600 cal. BC, a lagoonal environment subsequently formed. Navigation might still have been possible at this time; however, the likely development of coastal spits possibly made sea-faring difficult during the 2 nd millennium BC in this zone, as for the Anapa spit situated on the Black Sea shore of the peninsula (Izmailov, 2007). Therefore, ancient navigation essentially centred on the Bosphorus of Temryuk.

\subsubsection{Central Bosphorus (Temryuk Bosphorus)}

The central Bosphorus was located on the eastern side of Taman island. This channel was washed by the sea for longer because it was wider than the eastern one and lay further from the mouth of the Kuban and its sedimentary sources. As the settlements of Labrys (Brückner et al., 2010) and Golubitskaya 2 (Kelterbaum et al., 2011) demonstrate, many of the settlements founded by Greek colonists lay on the coastline of the palaeo-Bosphorus of Temryuk. The association of this low-energy shallow marine and lagoonal environment, which was perfect for natural anchorages and navigation, and the fertile soil developed from loess explain the significant number of ancient settlements on the peninsula.

According to Fouache et al. (2012) and Schlotzauer and Zhuravlev (2014), in the centre of the present peninsula, near the settlement of Strelka, the marine-lagoonal environment present during the Greek colonisation persisted until the 9th century AD. In this area, the water column was between 2 and $3 \mathrm{~m}$ deep, i.e. deep enough for ancient ships to navigate (vicinity of core DZHI2). But, this area had probably been transformed into a lagoonal environment by around 2000 years ago, separated from the sea by several coastal spits as suggested by the study of Kelterbaum et al. (2011). Supplementing the study of Izmailov (2007), he precisely dated the evolution of these coastal spits on either side of Golubitskaya palaeo-island (Fig. 5d). Spit formation began at the beginning of the 3rd millennium BC. This growth seems to be the major reason for the abandonment and land locking of Golubitskaya 2, probably during the 2nd century BC (Kelterbaum et al., 2011). The positive sedimentary budget inside the central Bosphorus is also largely due to significant cliff erosion linked to wave action as, for the Strait of Kerch today testifies (Fig. 6). High sediment supply accelerated the infilling of harbour basins and anchorages resulting in their abandonment. The ideal environmental conditions found by Greek colonists ca. $600 \mathrm{BC}$ were shortlived, and the coastal environment evolved in a relatively short time period due to a rapid sedimentation in a context of limited accommodation space.

\subsubsection{Cimmerian Bosphorus (Strait of Kerch)}

The Strait of Kerch, with a length of around $35 \mathrm{~km}$ and a depth of up to $18 \mathrm{~m}$, is bounded by the Crimean coastline and the Taman Peninsula that lie 4.5 to $15 \mathrm{~km}$ apart. In the centre, on the Taman Gulf, several Greek city-states were founded. Phanagoria, the most important of them on the eastern side of the Cimmerian Bosphorus is considered to have been the capital of the Asian Bosphorus Kingdom. The coastlines of this channel have not been significantly impacted by siltation because the accommodation space is significant. Nonetheless, sand spits and beach barriers have formed on this Bosphorus, such as the Tcouchtchka spit between Taman and Crimea. The main driver of present day environmental changes is coastal erosion (Fig. 6). At present, some ancient archaeological sites are threatened by erosion, and coastal management projects have been put into place to alleviate this significant problem (Fig. 7).

\section{Conclusion}

The Taman Peninsula offers a wealth of long-term research opportunities, both from geomorphological and archaeological perspectives. Geomorphological studies have shown the creation of three palaeochannels connecting the Black Sea and the Azov Sea around the former islands of the Taman archipelago following the marine transgression with its peak ca. 6000 years ago. The Eastern Bosphorus (Kuban Bosphorus) was closed about 2600 years ago, at least 1500 years before the Greek colonisation of the northern Pontic area about 2600 years ago. Conversely, a central Bosphorus (Bosphorus of Temryuk), larger and further from the sedimentary sources, formed a protected shallow

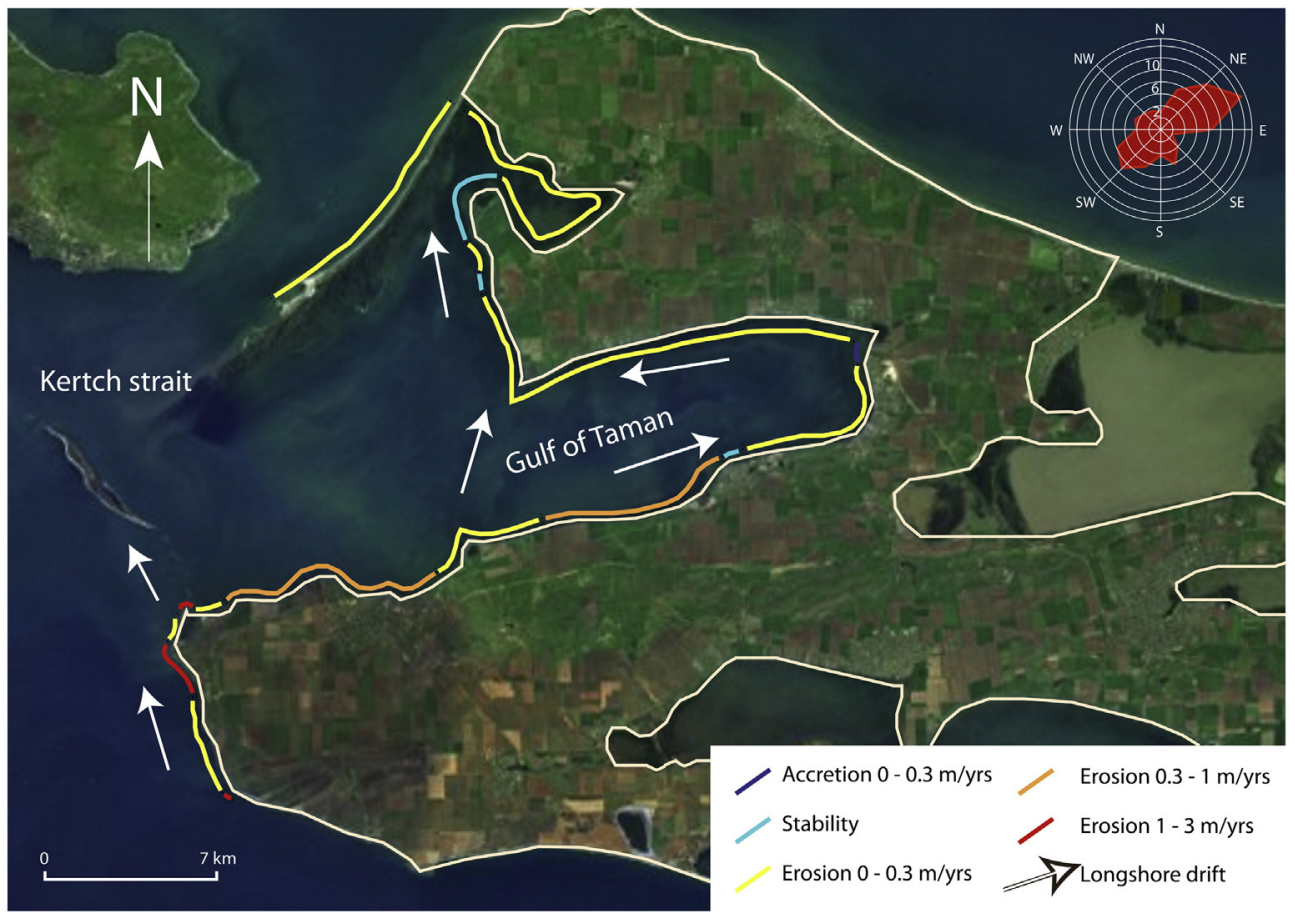

Fig. 6. Present erosion rates along the coasts of the Taman Gulf after Peshkov (2003) (Windrose from windfinder.com/in knots, Image GoogleEarth). 


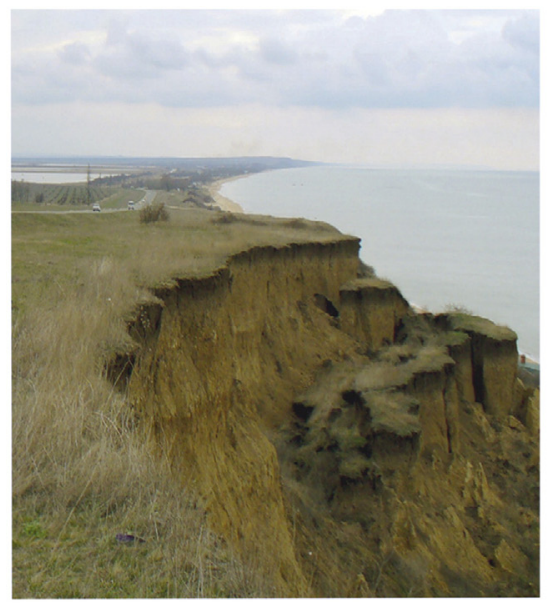

a.
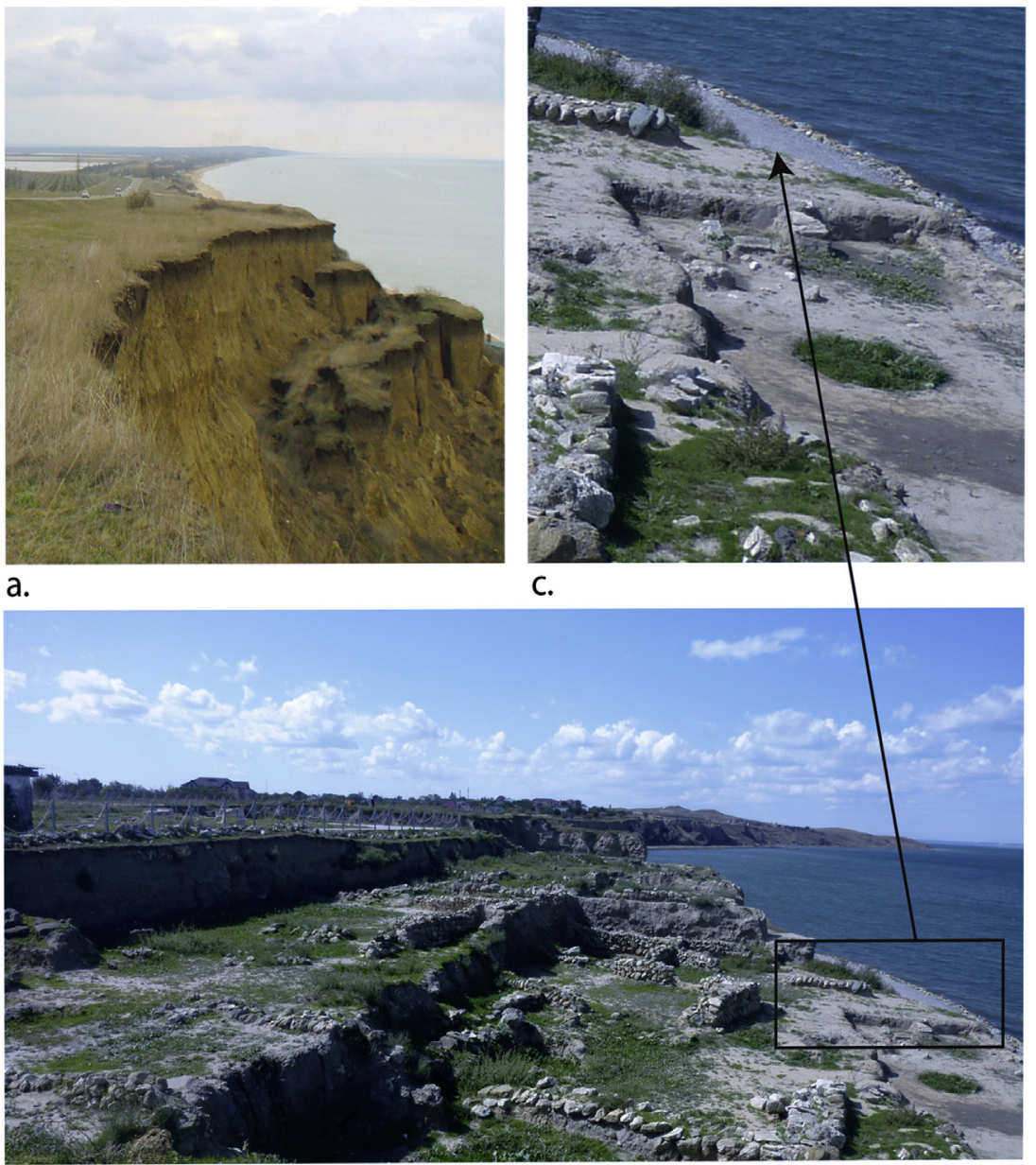

b.

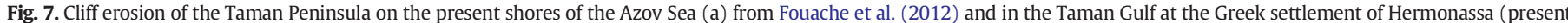
Taman) which is rapidly being lost to the sea (b). Zoom on engineering structures to control erosion at Hermonassa (c).

marine to lagoon environment that was conducive to the installation of natural harbours until around 2000 years ago. The evolution of sand spits and beach barriers subsequently connected the different islands. Without direct access to the sea, the city-states of the palaeoBosphorus of Temryuk were gradually abandoned.

\section{Acknowledgements}

This study was supported by the following projects: Institut Universitaire de France, CLIMSORIENT and Geoarchaeology of Ancient Harbours. This work was undertaken within the framework of the GEOMED-A*MIDEX project (no. ANR-11-IDEX-0001-02) funded by the French Government's "Investissements d'Avenir", managed by the French National Research Agency (ANR). We thank Patrick Pentsch for his help in preparing some of the illustrations. Daniel Kelterbaum and Helmut Brückner would like to thank the German Archaeological Institute (DAI), especially Dr. Udo Schlotzhauer. The Russian authorities kindly granted the research permits.

We thank the Eccorev federation and the sedimentology laboratory of the CEREGE (D. Delanghe-CEREGE) for the funding of the binocular microscope Leica MZ125.

\section{References}

Abramov, A.P., Zavoykin, A.A., 2003. Patraeus - Cimmeris - Achilleion. In: Grammenos, D.V., Petropoulos, E.K. (Eds.), Ancient Greek Colonies in the Black Sea, Thessalonique, pp. 1103-1154.
Anthony, E.J., Marriner, N., Morhange, C., 2014. Human influence and the changing geomorphology of Mediterranean deltas and coasts over the last 6000 years: from progradation to destruction phase? Earth Sci. Rev. 139, 336-361.

Athersuch, J., Horne, D.J., Whittaker, J.E., 1989. Marine and Brackish Water Ostracods (Superfamilies Cypridacea et Cytheracea): Keys et Notes for the Identification of the Species. In: Brill Archive (Ed.) , p. 366 New Work.

Bondesan, M., Castiglioni, G.B., Elmi, C., Gabbianelli, G., Marocco, R., Pirazzolij, P.A., 1995 Coastal areas at risk from storm surges and sea-level rise in northeastern Italy. J. Coast. Res. 11 (4), 1354-1379.

Brückner, H., Kelterbaum, D., Marunchak, O., Porotov, A., Vött, A., 2010. The Holocene sea level story since $7500 \mathrm{BP}$ - lessons from the Eastern Mediterranean, the Black and the Azov Sea. Quat. Int. 225 (2), 160-179.

Brückner, H., Vött, A., Schriever, A., Handl, M., 2005. Holocene delta progradation in the eastern Mediterranean - case studies in their historical context. Méditerranée 104, 95-106.

Cimerman, F., Langer, M.R., 1991. Mediterranean Foraminifera. Academia Scientarium et Aritium Slovenica, Dela, Opera 30, Classis IV: Historia Naturalis (118 pp., 93 pl.).

Coleman, J.M., Wright, L.D., 1975. Modern river deltas variability of processes and sand bodies. In: Broussard, M.L. (Ed.), Deltas, Models, for Exploration. Houston Geological Society, Houston, TX, pp. 99-149.

Finogenova, S.I., 2003. Hermonassa. In: Grammenos, D.V., Petropoulos, E.K. (Eds.), Ancient Greek Colonies in the Black Sea, Thessalonique, pp. 1007-1046.

Fouache, E., Kelterbaum, D., Brückner, H., Lericolais, G., Porotov, A., Dikarev, V., 2012. The late Holocene evolution of the Black Sea - a critical view on the so-called Phanagorian regression. Quat. Int. 266 (2012), 162-174.

Fouache, E., Porotov, A., Müller, C., Gorlov, Y., Bolokhovskaya, N., Kaitamba, M., 2005 Relative sea-level changes throughout the last 6000 years on the Taman Peninsula (Black Sea, Azov Sea, Russia): a geoarchaeological study. Revista de Geomorfologie 7, 7-20.

Garbuzov, G.P., 2003. Structure de l'aménagement foncier antique de la Péninsule de Taman (en russe). Rossijskaja Arheologia 3, 61-70.

Giaime, M., Baralis, A., Marriner, N., Morhange, C., Porotov, A., 2014. D'un archipel à une plaine deltaïque : géoarchéologie de la Péninsule de Taman (Sud-Ouest de la Russie). Géochronique 130, 42-45. 
Izmailov, Y., 2007. Late Holocene coastlines of the Azov Sea in the Kuban River Delta. In: Chepalyga, A., Izmailov, Y., Zin'ko, V. (Eds.), Field Trip Guide. IGCP 521 - 481 Joint Meeting and Field Trip, Fig. 18a, p. 36.

Kaniewski, D., Giaime, M., Marriner, N., Morhange, C., Otto, T., Porotov, A.V., Van Campo, E., 2015. First evidence of agro-pastoral farming and anthropogenic impact in the Taman Peninsula, Russia. Quat. Sci. Rev. 114, 43-51.

Kaplin, P.,.A., Selivanov, A.O., 2004. Lateglacial and Holocene sea level changes in sem enclosed seas of North Eurasia: examples from the contrasting Black and White Seas. Palaeogeogr. Palaeoclimatol. Palaeoecol. 209 (1-4), 19-36.

Kelterbaum, D., Brückner, H., Porotov, A., 2011. Geoarchaeology of Taman Peninsula (Kerch Strait, South-West Russia) - the example of the ancient Greek settlement of Golubitskaya 2. Contrib. Geoarchaeol. DIE ERDE 3 (3), 235-258.

Kuznetsov, V.D., 2003. Kepoi - Phanagoria - Taganrog. In: Grammenos, D.V., Petropoulos, E.K. (Eds.), Ancient Greek Colonies in the Black Sea, Thessalonique, pp. 895-956.

Loeblich, A.R., Tappan, H., 1988. Foraminiferal Genera and their Classification (2 vols). Van Nostrant Reinhold, New York (xi +970 pp.; ix + 213 pp. + 847 plates).

Lamb, A.L., Wilson, G.P., Leng, M.J., 2006. A review of coastal palaeoclimate and relative sea-level reconstructions using $\delta 13 \mathrm{C}$ and $\mathrm{C} / \mathrm{N}$ ratios in organic material. Earth $\mathrm{Sci}$. Rev. 75 (1-4), 29-57.

Marra, F., Bozzano, F., Cinti, F.R., 2013. Chronostratigraphic and lithologic features of the Tiber River sediments (Rome, Italy): implications on the post-glacial sea-level rise and Holocene climate. Glob. Planet. Chang. 107, 157-176.

Marriner, N., Flaux, C., Morhange, C., Kaniewski, D., 2012. Nile Delta's sinking past: quantifiable links with Holocene compaction and climate-driven changes in sediment supply? Geology 40 (12), 1083-1086.

Maslennikov, A.A., 2003. In: Grammenos, D.V., Petropoulos, E.K. (Eds.), Ancient Greek Colonies in the Black Sea, Thessalonique, pp. 1155-1213.

Meyers, P.A., 1997. Organic geochemical proxies of paleoceanographic, paleolimnologic and paleoclimatic processes. Org. Geochem. 27 (5/6), 213-250.

Mikhailov, V.N., Povalishnikova, E.S., Ivanov, A.A., 2002. Water level fluctuations in the Kuban River Delta over the period of many years. Water Res. 29, 115-122.

Morhange, C., Marriner, N., 2010. Paleo-hazards in the coastal Mediterranean: geoarchaeological approach. In: Martini, I.P., Chesworth, W. (Eds.), Landscapes and Societies. Springer Netherlands, Dordrecht, pp. 223-234.

Müller, C., Fouache, E., Gorlov, Y., 1999. Péninsule de Taman (Russie Méridionale). Bulletin de correspondance Hellénique vol. 123, pp. 589-598 (livre 2).
Murray, J.W., 2006. Ecology and Applications of Benthic Foraminifera. Cambridge University Press, New York (426 pp.).

Peshkov, V., 2003. The coastal zone: the Sea of Azov and Black sea. Krasnodar. "Lakont", Technical report p. 350 (in russian).

Porotov, A., 2007. Relative sea-level changes and submersion of archeological sites along the northern shoreline of the Black Sea. Méditerranée 108, 29-36.

Reimer, P.J., Bard, E., Bayliss, A., Beck, J.W., Blackwell, P.G., Ramsey, C.B., Buck, C.E., Cheng, H., Edwards, R.L., Friedrich, M., Grootes, P.M., Guilderson, T.P., Haflidison, H., Hajdas, I., Hatté, C., Heaton, T., Hoffmann, D.L., Hogg, A., Hughen, K.A., Kaiser, K., Kromer, B., Manning, S.W., Niu, M., Reimer, R., Richards, D.A., Scott, E.M., Southon, J.R., Staff, R., Turney, C., Van der Plicht, J., 2013. IntCal13 and Marine13 Radiocarbon Age calibration Curves 0-50,000 years cal BP. Radiocarbon 55, 1869-1887.

Reineck, H.E., Singh, I.B., 1975. Depositional Sedimentary Environments. Springer-V, Berlin (439 pp.).

Saintot, A., Angelier, J., 2000. Plio-Quaternary paleostress regimes and relation to structural development in the Kertch-Taman peninsulas (Ukraine and Russia). J. Struct. Geol. 22 (8), 1049-1064

Sampei, Y., Matsumoto, E., 2001. C/N ratios in a sediment core from Nakaumi Lagoon, southwest Japan. Usefulness as an organic source indicator. Geochem. J. 35 (3), 189-205.

Schlotzauer, U., Zhuravlev, D., 2014. Greek colonization in the Cimmerian Bosporus: Russian-German interdisciplinary investigations in southern Russia. Proceedings of the Conference "Tyritake. Antique Site at Cimmerian Bosporus" Held on 27-28 November 2013 at the National Museum in Warsaw. The National Museum in Warsaw, Warsaw, pp. 203-219.

Stanley, J.-D., 1997. Mediterranean deltas: subsidence as a major control of relative sealevel rise, in "Transformations and evolution of the Mediterranean coastline". Bull. Inst. Oceanogr Monaco Sci. Ser. 3, 35-62.

Stuiver, M., Reimer, P.J., 1993. Extended 14C database and revised CALIB radiocarbon calibration program. Radiocarbon 35, 215-230.

Teatini, P., Tosi, L., Strozzi, T., 2011. Quantitative evidence that compaction of Holocene sediments drives the present land subsidence of the Po Delta, Italy. J. Geophys. Res. 116, B08407.

Wilson, G.P., Lamb, A.L., Leng, M.J., Gonzalez, S., Huddart, D., 2005. Variability of organic $\delta 13 \mathrm{C}$ and $\mathrm{C} / \mathrm{N}$ in the Mersey Estuary, U.K. and its implications for sea-level reconstruction studies. Estuar. Coast. Shelf Sci. 64 (4), 685-698. 